\title{
Research on the application of computer aided Design in clothing Design teaching in higher vocational colleges
}

\author{
ZHANG Ninga,b, Eakachat Joneurairatanac* \\ ${ }^{a, b}$ Faculty of Decorative Arts, Silpakorn University, Bangkok, 10200, Thailand \\ ${ }^{\mathrm{b}}$ Scientific Research Department, Jiangxi Institute of Fashion Technology, Nanchang 330201, Jiangxi, China \\ *Corresponding Author: tristan777@163.com
}

Article History: Received: 10 November 2020; Revised 12 January 2021 Accepted: 27 January 2021; Published online: 5 April 2021

\begin{abstract}
This research expounds the computer aided design application in modern fashion design teaching present situation, and ordering in teachers working task, based on the typical types of clothing products to enterprises as the teaching content of the carrier, the enterprise real tasks in classroom teaching method, attach importance to students learning and the consistency of the practical work, takes student's practical teaching, explore the classroom and the requirements of the enterprise integration technology Innovative..
\end{abstract}

Keywords: Computer-aided design, Practical teaching, Technology innovation

\section{Introduction}

At present in the art colleges, universities, professional fashion design at the university of professional teaching, the understanding of computer aided design are two concepts: the first is a concept of "pure instrumental, believe that the computer is just a tool, a have aided design method in the design process of tools, it is always an aided design means, like a pen and a ruler, a computer aided design teaching just technical teaching, it is difficult to be combined with professional.

The second is "pure art" concept, pay much attention to the teaching of computer aided design, think that the computer is a kind of "independent" complete costume design "subject", so put a lot of effort in the teaching to explore the clothing computer art expression ability and form, which makes the teaching from the realistic need and reach the purpose of the design.

In fact, both of these concepts are the result of traditional art design teaching and the lack of ontology knowledge of clothing COMPUTER-aided design.

In the rapid development of the clothing industry, facing the competition of domestic and foreign clothing brands, the clothing industry has borne great pressure and challenges.

The key to the faster and more comprehensive development of the garment industry is to improve the innovation of garment styles and the novelty of garment design. Only in this way can the garment industry develop to the direction of multiple varieties and high quality.

Clothing computer-aided design is a modern high and new technology integrating the knowledge of clothing effect design, clothing structure design, clothing industrial sample design, computer graphics, database, network communication and so on.

At present, computer aided design software has been widely used in garment design by major countries in the world to design styles, accessories and accessories.

\section{Objectives}

Nowadays, the continuous improvement of the economic system has promoted the prosperity and development of the garment industry.

With the continuous improvement of the living standard of the public, people have gradually put forward the demand of fashion and individuality for clothing, thus forming a huge gap of clothing design talents.

In the fashion design of colleges and universities, relevant professional education mode should keep pace with The Times, highlight professional characteristics, and devote to training students' innovative thinking ability. 
In recent years, computer technology has been widely promoted in the teaching of costume design in colleges and universities. However, the integration of technology and teaching is mostly limited to the innovation at the formal level.

Obviously, the integration of computer technology and costume design teaching in colleges and universities is not only a change in form, but also an innovation in teaching philosophy.

The fundamental idea of clothing design teaching in colleges and universities lies in the full integration of art and craft, which greatly influences the role of computer technology as an auxiliary teaching means.

By the sichuan fine arts institute master tutor, professor Yu Ning by an introduction to fashion design, based on the basic knowledge of fashion design, covering the historical development of clothing, costume design, creative thinking, aesthetic principles and application of the clothing modelling, fabric and decoration, the popularity of fashion and brand marketing, etc., to the costume design teaching and other related knowledge at the same time also has carried on the brief summary and orderly integration, in order to help students have a comprehensive, system to fashion design, in-depth understanding and awareness.

It is mentioned in the book that costume design is a subject with strong practicality, and the application significance of computer-aided design in the teaching of costume design in colleges and universities. First of all, it can improve the efficiency of classroom teaching.

Computer-aided teaching of costume design in colleges and universities can not only save a lot of teaching time, but also reduce the impact caused by human error, so as to improve the efficiency of classroom teaching. hand.

For example, in classroom teaching, it will take a lot of time for students to draw costume design drawings by

With the introduction of computer-aided design, students can draw clothes with Photoshop more efficiently and conveniently. Moreover, they can quickly draw colors and background colors by computer, and solve problems timely and effectively.

Compared with hand-painted design drawings, computer-aided design drawings can reduce students' learning burden and effectively mobilize their learning initiative.

Secondly, it can promote the storage and sharing of resources.Computer-aided design can realize convenient query and mass storage, so, the computer aided design application in fashion design course teaching, not only many teaching materials, images can be stored in the computer, and student to complete the design of the work can be stored in the computer, save the traditional hand-painted drawing occupies space.

Finally, teaching methods can be optimized.

The application of COMPUTER aided design in college clothing design teaching is a reform and innovation of traditional teaching methods.

This teaching method can innovate teachers' traditional teaching thinking and set up a talent cultivation idea which is more in line with teaching practice.

In addition, nowadays, computer clothing design and production have been promoted in many clothing enterprises. The effective combination of clothing design teaching and computer technology in colleges and universities effectively connects the social reality and promotes the improvement of students' social practice ability.

As the global economy enters the winter due to the regional situation and the impact of COVID-19, the production and investment of the garment industry are significantly slowed down. The development mode of the industry is changing from scale expansion to benefit expansion. The operation quality is significantly improved, and the demand for highly skilled personnel is also increased accordingly.

At present, There are about 140,000 garment manufacturers in China, while only about 8,000 enterprises use computer-aided garment design, which means that the market penetration rate of computer-aided garment design in China is only about $17.6 \%$.

How to solve the problems of computer-aided design in the teaching and application of modern clothing design is a problem worthy of our great attention.

Based on the platform of clothing graphic design software and the diversified and personalized development and needs of current clothing design, the author intends to study how to carry out the application of computeraided design in the teaching of modern clothing design.

Its purpose in his employment as the guidance, in the "university-enterprise cooperation and work-integrated 
learning" as the breakthrough point, in the teaching, focusing on the professional ability training based on working task, USES the enterprise real project, integrating ordering teaching content, teaching and work, so as to realize the theory and practice depth fusion, in order to improve the professional ability of students.

\section{Methodology}

Higher vocational colleges focus on cultivating students' practical working ability, enabling them to master skills and have employment competitiveness, so that they can work after they leave school.

Teachers carry out teaching with project as the core, assess students with enterprise standards, and integrate theory and practice, which is helpful to improve students' clothing design ability.

\subsection{Traditional teaching mode}

The teaching mode of clothing specialty in Chinese universities has long been adopted by traditional teachers.

This way of training students in the actual work there is a big defect, that is, the thinking ability is not strong, professional quality is not enough, the scope of knowledge is not wide, resulting in the later development potential is not enough.

Therefore, how to reflect the service and practicability of clothing CAD in the course teaching of clothing design specialty, and improve the teaching mode and practice of clothing CAD course;

How to cultivate students' innovative consciousness and creative ability and improve the social practicality of professional personnel training is an urgent problem.

\subsection{The new mode of teaching reform}

In the teaching reform of COMPUTER-aided design, teachers should go deep into enterprises, and on the basis of full investigation, induction and sequencing of post work tasks, take the clothing types of typical products of enterprises as the project carrier of teaching content, and bring the real work tasks of industrial enterprises into classroom teaching.

Pay attention to the consistency between students' study and actual work in teaching, so that the whole teaching process revolves around work tasks.

Teachers should attach importance to the assessment requirements of students' on-campus learning and enterprise standards, combine the assessment of students' performance on campus with the assessment of enterprise requirements, and explore the integration of classroom and enterprise requirements.

\subsection{Methods of practical teaching reform}

In terms of professional teaching, taking the course of Clothing Computer Design as the carrier, adhering to the principle of "teaching, learning and doing in one" in teaching methods, teachers are organized to participate in the research of task-driven teaching, project teaching, discussion teaching, inquiry teaching and other teaching methods.

According to the characteristics of college education and the requirements of the society for students' post skills, the unique teaching rules and characteristics of this course are comprehensively considered, and the role of each skill in practical application is emphasized in the teaching process.

In the classroom, case teaching method is mainly adopted. Teachers create scenarios, assign tasks, provide learning materials, and use group cooperation to let students complete the learning tasks independently.

Outside the school, teachers actively cooperate with enterprises and add more scientific and practical contents in teaching through the communication and cooperation between teachers and enterprises.

Teachers in fully research, inductive, ordering post, on the basis of work tasks, in a typical product range as the teaching content of the carrier, the industry enterprise real tasks in classroom teaching, the teaching contents design into multiple projects and learning task, put theoretical knowledge into skills, attention to students learning and the consistency of the practical work, make the whole process of teaching all around the work task.

In terms of performance assessment, the integration of classroom and enterprise requirements should be explored by combining the assessment of students' performance in school with the assessment of enterprise requirements.

Actively carry out order training, and explore teaching modes conducive to enhancing students' design ability, such as work-study alternations, task-driven, project-oriented and in-post internship; 
We should guide enterprises to establish a system for accepting students from vocational colleges for internship, strengthen students' production practice and social practice, and ensure that students in colleges and universities have at least half a year to work in enterprises and other employing units for internship.

Work-integrated learning is the nature of education through the combined closely with the enterprise and the social demand, colleges and universities should be according to the need for enterprise staff and students of vocational training, in collaboration with the enterprise application research and technology development, make the enterprise in the share of school resources at the same time, participate in the reform and development of schools, schools in university-enterprise cooperation innovation personnel training mode.

\subsection{The difficulty of practical teaching}

Clothing computer-aided design is a highly practical

course. In order to comprehensively cultivate students' skill level, we consider adopting "three-stage" teaching for practical teaching, namely "early experimental teaching" + "middle practical teaching" + "late practical teaching".

"Three-step" practice teaching overcomes the defect of the past a single experiment, through the basic experiment to the comprehensive experiments, from the curriculum design to the field practice teaching process, from shallow to deep, gradually thorough, from theory to practical application, step by step, in line with the students' skill development rule, so that the students in the process of practice teaching system to get exercise and training, so as to improve students' practical ability, so that the students can according to the requirements of the user or market products independently design and manufacture, some students can also innovate design.

\subsection{Deepen cooperation between schools and enterprises}

Teachers should teach relevant course contents according to each link of the work process, and attach importance to the consistency between students' study in school and their actual work.

The advanced 3d anthropometric technology can be flexibly incorporated into students' daily learning tasks, so that students can do it in teaching and learning.Only by integrating advanced technology into practice teaching can we keep pace with The Times better.

Teachers must take the cultivation of students' vocational ability as the main line, and carry out the integrated teaching of "teaching, learning and doing" based on the working process in the campus practical training base.

Each action orientation integrates the learning of theoretical knowledge into various tasks with the six-step approach of "information - decision - plan - implementation - inspection - evaluation".Teachers should organically combine theoretical explanation with students' actual work process, extend from single classroom practice to complex comprehensive skill training, productive practice, on-the-job practice and other processes, and focus on improving students' ability to understand and solve problems, and strengthen students' professional ability cultivation.

\subsection{Verify theoretical knowledge with practical operations}

The characteristic of higher vocational education is to cultivate students' post skills. The teaching should focus on technical operation and emphasize students' application ability of garment design.

However, costume design itself is also an artistic design. It should not only cultivate students' application of design software, but also guide their independent consciousness and aesthetic consciousness.

When students apply computer design software to design clothes, teachers should use multimedia courseware to show excellent clothes design works to students, so that students can realize that computer design clothes can also make clothes more artistic.

Teachers should actively cooperate with the enterprise, and garment enterprises of the designer to communicate for computer aided design of related problems, some scientific and practical content into the teaching, let students learn knowledge derived from the enterprise practice, causes the student to enter the computer aided design jobs after quickly familiar with their work, realize the importance of design art.

By integrating the operation technology of COMPUTER-aided design into theoretical knowledge and sublimating the theoretical knowledge into professional knowledge, students' learning consciousness of computeraided design will be enhanced, which is very beneficial to the cultivation of innovative talents.

\section{Conclusion}

To sum up, the research proves that the computer clothing design course under the school-enterprise cooperation mode is a certain advanced teaching mode. 
Combined with the teaching method of "teaching, learning and doing in one", the teaching method of "business driven teaching", "project teaching", "discussion teaching", "inquiry teaching" and other teaching methods can quickly enable students to grasp the real technical needs of enterprises in a relatively short time.

Teachers should on the basis of a variety of the range of production technology, make full use of the training base to carry out the integration of face-to-face teaching, let the student much earlier access to today's advanced equipment and technology, so that students learn better and faster to use clothing computer design software, and a variety of different types of clothing design, lay the foundation for broadening the employment channels.

With the rapid development of computer science and information technology, garment CAD technology is also developing at a rapid speed. Intelligent, integrated and networked garment CAD technology is still the general trend of the future development of modern garment CAD technology, which will greatly promote the development of the garment industry and make greater contributions to improving the production efficiency of the garment industry..

\section{References}

Lu Yingfeng. "Project style" teaching reform model of fashion design major, Journal of Baoding Vocational Technical College, Hebei, China, 2011(02).

LingJun. Seamless connection from 3D anthropometry to Garment CAD/CAM, China Garment Manufacturing, 2011(04).

Yu Qiang. An Introduction to Fashion Design, China Textile Press, China, 2009.

Wang Yaqun. On the teaching practice of computer-aided Design in clothing Design major, Digital Design publishing, Beijing, China, 2017

Hou Ling. Research on the application of COMPUTER-aided Design in the teaching of costume Design in colleges and universities, China Academic Journals Electronic Home, China, 2018. 